\title{
Investment Attractiveness of the Area and the Possibility of Its Increase by Reducing the Shadow of Economic Processes
}

\author{
Novenkova A.Z. \\ Kazan Federal University, Kazan, 420008, Russia \\ Abdulganiev F.S. \\ Kazan Federal University, Kazan, 420008, Russia \\ Email address: followaida@gmail.com.
}

Doi:10.5901/mjss.2014.v5n18p73

\begin{abstract}
The article focuses on the analysis of the system of shadow sector of regional economy influencing investment flows in to a regions economy. The natural variety of conditions in different regions of Russia defines a number of factors of investment appeal. Necessity of quality improvement of management of the region, particularly concerning regulation of tendencies of development of shadow economy, is asserted; it causes increase of tax revenues and provides decrease in the unemployed in the region. Forecasting of corresponding tendencies was made by the example of the Republic of Tatarstan in the frames of current, innovative and complemented scenarios.
\end{abstract}

Keywords: shadow economy, transparency, public management, image component of investment attractiveness of the territory, rent-seeking behavior of state run public authorities, transaction expenses, publicity.

\section{Introduction}

Resulting vector of development of modern economics is greatly determined by relationship of opposite tendencies of globalization and regionalization which are manifested on all stages of social reproduction and in all spheres, and this causes necessity of development of qualitatively new management technologies on macro-, meso- and micro-levels. Implementation of centrifugal and centripetal processes causes changes in shadow economy matter which includes, according to recommended by UN methodological approach, concealed or legislatively permitted, but officially nonregistering activity in the frames of formalized structures and procedures, informal, or legislatively permitted but nonregistering activity of informal structures, illegal or legislatively forbidden activity. It is expressed, from one side, in unification of mechanisms of activity which is not taken into account by the state, in activation of multinational and multiregional resource flows which are not controlled by public authorities, from the other side, in spectrum broadening of business activities determined by peculiarities of the environment of economic agents.

According to the data from World Bank, in 2010 in the Russian Federation the volume of shadow economy was about $48,6 \%$ of GDP, in Russian regions this index is within the limits of $20-50 \%$ of GRP [3]. In 2010 Federal State Statistics Service оценивала estimated shadow economy in 14-16\% of state GDP [1]. Such difference in estimates of volumes of shadow economy by international organizations and Russian official statistical authorities is determined by difference in methodical approaches for identification of its borders and ways of evaluation of range of activity, as well as by difficulty of obtaining objective data concerning economic activity which is not controlled by the state. However, transformation of shadow economy into the integral part national economic system is decided, and it is caused by the variety of reasons; inefficiency of institutional environment characterized by absence of complementarity of existing and new institutions, institutional gaps because of lags of legal regulation from social-economic development rates; high tax burden that interferes legitimation of business activity; corruptness of state machinery that causes high transaction expenses; low level of transparency and publicity in activities of bodies of legislative, executive and judicial power, are among them.

Corruption has significant effect on direction and dynamics of development of the country in whole and its regions. According to the data from International non-governmental organization " Transparency International", in 2011 the Russian was on the $143^{\text {rd }}$ place from 183 possible with the index of 2,4 points according by the level of perception of 
corruption [2], whereas in 2010 it was on the $154^{\text {th }}$ place from 178 with index of 2,1 points. Some positive changes are caused by introducing and passing anti-corruption legislation which determines the main legal parameters of prevention of corruption in public sector. At the same time such laws control and restrain bribery and evasion of the tax payment as elements of shadow economic activity are important factors of budget deficit and decrease of total revenue only de minimis.

\section{Methodology}

Start of study of shadow economic relations was in the 70s of the XX century in the works of K. Hart, R. Bromley, G. Mead, C. Morrison who analyzed illegal employment in the countries of the third world. Modern paradigm of theories of shadow economic sector is mainly determined by views of $\mathrm{H}$. De Soto who considers shadow economic relations as the factor of steady development. V. Cartaya, G. Marquez, G. Mezera, V. Tokman devoted their works to research of some aspects of unaccounted business activities. Attempt to use Marxist methodology for analysis of shadow economic sector was made in the works of M. Castells and A. Portes.

In spite of considerable amount of work which touches upon different aspects of public management, the questions of legalization of shadow economic processes and phenomena in the context of the problem of improvement of the effectiveness of regional regulation were not studied thoroughly. A lot of theoretical and practical questions connected with definition of boundaries of the shadow sector and estimate of its extent, transparency of regional management as the factor of quality improvement of public services of management are still debatable and require additional research and background study.

The aim of the work is to develop and lay a scientific foundation for theoretical-methodological basis and practical recommendations concerning formation and development of the system of regulation of shadow economic sector as the necessary part of improvement of image component of investment attractiveness of territorial subdivisions.

Research of the shadow sector of regional economy allowed to offer the author's approach to its structure which differs from the one that is used in practice of the countries with developed market economy and which takes into account peculiarities of modern Russia. According to this approach, shadow economy consists of the following parts: household economy in the frames of which distinct contract relations are regulated by informal institutions only (traditions, social capital, social trust, etc.) without violation of formal restrictions; shadow, or criminal economy as the complex of hidden contracts with participation of unregistered according to the established procedure entities of business activities which are executed with violation of formal institutions (laws, regulations) despite enforcement mechanisms which provide observance of institutional restrictions that takes the form of economic crimes; unfixed economy as complex of hidden contracts executed by agents of legal economic sector (registered according to the established procedure entities of business activities, bureaucratic apparatus, managers) with violation of formal restrictions which takes the form of tax or other offences; unaccounted, or, unobserved, economy as the complex of hidden contracts executed with violation of requirements of financial state control or other forms of state control with participation of agents of legal economic sector (accounting misstatements, falsification of figures, falsification of data concerning production quality, etc.); informal economy itself as the complex of hidden contracts executed in accordance with informal institutions (opportunist rentseeking behavior of bureaucratic apparatus, entities of business activity, households).

\section{Conclusion}

Performance of social-economic functions aimed at overcoming (preventing) market "failures" by the state presupposes control of access for limited resources on the basis of specification of ownership direct authority, as well as access for potential counterparts, for participation in the system of contract relations. Performance of the entrance control function by the state causes distortions of structure of interactions and gives sustainability to the last ones because of its security from bankruptcy threat. The function of access control is implemented in the frames of restricted interaction field which has institutional, special and economic nature.

Restrictions of institutional character are caused by information asymmetry and big expenses of monitoring of activity of governmental authorities for principals. They are presented by complex of formal and informal institutions and sanctions that implements their performance. Restrictions of special character are connected with detachment of relatively independent regional subdivisions as a part of national economic space, in 3D (tridimensional) measurement of which (economic time, transactions, business competition) dynamic sequence of contracts with participation of local community, business entities of the territory of environment and regional authorities, is implemented. Restrictions of economic character presuppose big expenses of entrance into subject area of territorially localized transactions and of 
exit from it - license payments, registration fees, restrictions imposed on repatriation of income of non-residents; system of residence permits for general public; expenses of support of subject matter - membership fees, size of authorized capital.

Regulation of production takes the form of absolute prohibitions or partial bans which result in increase of transaction expenses in the legal economic sector and increase of shadow sector share. Monopoly preferential benefits as the form of prohibition are implemented in the form of state-owned corporations (government business enterprises); virtual cartels (multicorporate enterprises) in case of assigning quotas for production of enterprises of this sectoral affiliation; licenses; quality standards; custom fees and other measures as a fine from manufacturers from other regions; fines in the frames of anti-monopoly and environmental protection legislation; patents, etc. Authorization of the state for the function of definite limitations and access control predetermines potential possibility for regional authorities to gain income from implementation of legal powers for benefits or for income from previous use or from permission for other agents to use relatively limited long-term assets, right for capital value of which does not belong to them. Such income takes the form of administrative-status rent.

There are factors that restrict ability of regional authorities for entrance control: imperative aspiration for encouragement of investments into regional economy; interaction fields set up with participation of regional subdivisions that co-exist and partially intercrossing on macro- and meso-levels (network formations, vertically integrated structures, special economic zones); increase of mobility of resources in conditions of globalization; informational support of society; activity of some non-governmental organizations that provide transparency of public administration. At the same time control for resources with immobility (natural resources) increases rent-seeking character of activity of regional authorities allowing to the last ones to redistribute rent for its own benefit.

High level of transaction expenses causes impossibility of elimination of shadow sector of regional economy. If transformation expenses are higher than transaction expenses of functioning of shadow relations, the relative share of revenues from shadow sector in overall volume of meso-economic indicators will be the same. Transaction expenses of functioning of entities of shadow economic relations in the region include expenses of information search in relation to services of public administration, counterparts, manufacturing factors and final goods which appear in the result of incompleteness and imperfection of information part of transactions; expenses of holding negotiations concerning drawing up and fulfillment of contracts (collateral, current and post-contract); expenses of measurement arising in the result of difficulty of determination of quality of goods (services, including public ones); expenses of specification and property rights protection; expenses of opportunist behavior of employees of state run public authorities, managers, households.

High level of transaction expenses is determined by low quality of functioning of public administration system, variance of chosen strategy and priorities of regional regulation to resource potential of economic agents, contradiction between new and imported institutions and contents of functioning institutional contour, by incompleteness of consideration of interests of economic agents, time gap between activity of economic process and its institutionalization.

In the frames of shadow economy qualitatively new institutions can form, later they transform into the part of the institutional contour of the regional economy (for example, instruments of financial market). In some cases the institutions of shadow sector duplicate and compete with formal restrictions forming existing institutional contour of regional economy. It contributes to improvement of the effectiveness of functioning of agents of regional economy (business activity without state registration and licensing).

Definite similarity is typical for restrictions that determine activities of the organized crime and the state (production of public goods in the form of provision of services for property rights protection), as well as of households (criminal organization cultivates relations of cooperation and mutual assistance). Thus, if in the frames of shadow sector of regional economy qualitatively new institutions or institutions, competing with institutions which function in legal economic sector, are formed, in this case regional economy is characterized by rather efficient distribution of resources. In this case economic objectives of unshadowing (improvement of regional legislation, reduction of administrative barriers, use of information technologies in cooperation with governmental authorities and public service customers, etc.) can be included into mid- and long-term programs of social-economic development of the region.

If transformation expenses are lower than transaction expenses of functioning of entities of shadow relations, in this case measures aimed at legalization of shadow sector can provide more effective distribution of resources which presupposes necessity of development and implementation of enforcement regional measures in short-term period (clampdown of responsibilities, control of compliance, etc.). Such measures become especially important in case of performing mainly the temporary closing-down function by institutions of shadow economy (when archaic institutions in this sector function for a long time with potential possibility of regeneration. Share of shadow economy in developed countries can be an indicative parameter (about $10 \%$ of GDP). 
Increase of efficiency and control performance of shadow economy in the region will help to provide, from one side, tax revenue increase of individual income tax and company profit what will happen as a result of exit of part of meso-level economy from darkness, as well as decrease of level of registered unemployment rate caused by possibility of legalization of some forms of work. In the frames of the research equations of linear regression which reflect dependence of dynamics of unemployment rate and dynamics of rate of profit-making enterprises from quality level of regional management were constructed on the basis of social-economic indicators of Volga region federal district in conditions of post-crisis development [15].

(1) $\Delta \mathrm{У}_{\text {без }}=1,9038-0,033 \mathrm{Y} K_{p y}$,

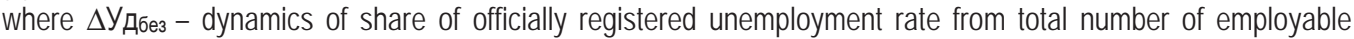
population, \%;

УK py - quality level of management of the region, score point $(0 \div 100)$.

(2) $\Delta y \partial_{n n}=-23,061+0,3984 \mathrm{Y} K_{p y}$,

where $\Delta \mathrm{V}_{\text {Дпп }}$ - dynamics of share of profit-making enterprises from total number of economic regional entities, $\%$.

Thus, quality improvement of management of the region, first of all in the part of regulation of tendencies of shadow economy development, causes tax revenue increase and provides decrease of unemployment rate in the region. Forecasting of corresponding tendencies was on the example of the Republic of Tatarstan in the frames of the following scenarios:

a) current, in the frames of which mechanisms and methods of regional management evolve in accordance with existing tendencies;

b) innovational, according to which mechanisms and methods of regional management are improved in the frames of implementation of innovative scenario of development of the Republic of Tatarstan;

c) complemented, in the frames of which mechanisms and methods of regional management are improved not only according to statements of innovative scenario of development of the Republic of Tatarstan, but on the basis of introduction of proposed in present work instruments of regulation of shadow economy as well.

Forecasting results are presented on pic. 1.

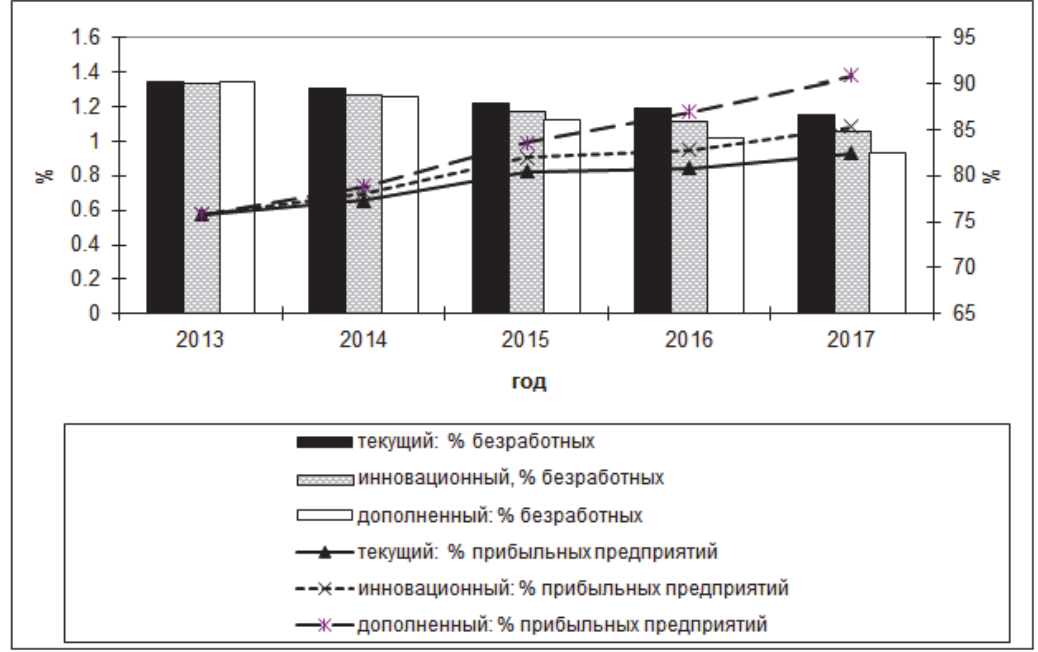

Pic. 1. Dynamics of unemployment rate and rate of profit-making enterprises of the Republic of Tatarstan for 2013-2017, $\%$ (forecast)

\section{Results}

As it is seen from the picture, in case of implementation of the complemented scenario unemployment level will decrease for $13,85 \%$, and rate of profit-making enterprises will increase for $6,49 \%$ in relation to innovative scenario for five years, and this indicates feasibility of implementation of measures to improve regional regulation of shadow economic sector in mid-term perspective. 


\section{References}

Data of Federal service of public statistics [Internet resource]. Access: www.gks.ru/, free.

Panasyuk, M.V., Bagautdinova, N.G., Safiullin, L.N., Novenkova, A.Z. Territorial approach to solving the region strategic management problems // World Applied Sciences Journal, 27(13), 2013, 149-153.

Bagautdinova N.G., Tsaregorodtsev E., Kulalayeva I., Arzhantseva N. Assessment of Mutual Probabilistic Influence of Volatility of Official Price for Precious Metals on the Market Value of the Bi-Currency Basket/l Mediterranean Journal of Social Sciences.Vol.5, No12, (2014)-pp.33-38.

Fakhrutdinova, E., Fakhrutdinova, A., Severyanov, O., Valeev, E. The transformation of educational approaches at the time of social and economical changes// World Applied Sciences Journal.Volume 27, Issue 13, 2013, Pages 15-19.

Safiullin L.N., Novenkova A.Z., Safiullin N.Z., Ismagilova G.N. Prospects of small business in Tatarstan. Life Science Journal 2014; $11(6 s): 396-399$.

Data of International non-governmental organization "Transparency International" [Internet resource]. Access: http://transparency.org/, free.

Bagautdinova N.G, Sabitov N.H, Salakhov B.R.,. Shakhnina I.Z Regional Banks in the System of Government Regulation of Economy/l Mediterranean Journal of Social Sciences.- Vol.5, No12, (2014)-pp.39-42.

Glebova I.S., Sadyrtdinov R. and Rodnyansky D. Impact Analysis of Investment Attractiveness of the Republic of Tatarstan on Fixed Investments of its Leading Companies // World Applied Sciences Journal 26 (7): 911-916, 2013.

Safiullin, M.R., Elstin, L.A., Shakirova, A.I. (2012). Evaluation of business and economic activity as a short-term forecasting tool. Herald of the Russian Academy of Sciences, 4, 290-294.

Data of World Bank. Access http://message.worldbank.org, free.

MacAfee K. A Glimpse of the Hidden Economy in the National Accounts // Economic Trends. 1980. Vol. 136. P. 81-87.

Frey B. S., Weck-Hannemann H. The Hidden Economy as an 'Unobserved' Variable // European Economic Review. 1984. Vol. 26/1. P. 33-53.

Safiullin L.N., Gafurov I.R., Shaidullin R.N., Safiullin N.Z. Socio-economic development of the region and its historical and cultural heritage. Life Science Journal 2014; 11(6s): 400-404.

Ajupov A. Definitions of concepts scope and interaction of risk-engineering on the financial market. Life Science Journal 2014; 11(6s): 337-340.

Bagautdinova N.G, Sarkin A.V., Averyanov B.A., Arzhantseva N. The Consept of "New" Paternalism and Its Realisation within The State Regualtion of Econom// Mediterranean Journal of Social Sciences.- Vol.5, No12, (2014)-pp.27-32.

Kundakchyan R.M., Zulfakarova L.F. Current issues of optimal capital structure based on forecasting financial performance of the company. Life Science Journal 2014; 11(6s): 368-371.

Schneider F., Buehn A., Montenegro C. E. New Estimates for the Shadow Economies all over the World // International Economic Journal. 2010. Vol. 24 (4). P. 443-461. 
